\title{
Piotr Nita
}

prof. dr hab. inż.

Instytut Techniczny Wojsk Lotniczych

piotr.nita@itwl.pl

DOI: 10.35117/A_ENG_20_02_04

\section{Dynamic interaction of military aircraft working on an cement concrete airfield pavement}

\begin{abstract}
The publication presents test results and analysis of the impact of military aircraft on an airport pavement made of pre-stressed panels. Three types of aircraft were used in the experiment, i.e. TS 11 ISKRA aircraft, SU 7 BM aircraft and SU-22 M4 aircraft. In the field tests, geophysical methods were used to measure the dynamic properties of the airport pavement structure. Based on the few vibration measurement methods of this type of construction that can be used, the vibration level of the pavement caused by the aircraft operating on that surface was recorded. The tests were carried out for various levels of aircraft thrust, the degree of harmfulness of the impact of generated vibrations on the pavement by sources of excitement, which were the above-mentioned aircraft, was assessed. Due to the fact that the research was one of the first to be carried out in the country, and such research is rare, there are no publications devoted to this issue also in foreign literature. Therefore, there are no reliable and credible criteria for assessing the impact of vibrations on these constructions. In the assessment of dynamic phenomena, by analogy, assessment methods and criteria related to general construction facilities were used. The most frequently used criteria for assessing dynamic interactions are based on the vibration speed criterion. The publication carried out an impact assessment based on the following criteria: vibrator scale, SWD scale and Zeller scale.
\end{abstract}

Keywords: Aircraft; cement concrete Airfield pavement; Frequency

\section{Introduction}

Cement concrete Airfield pavements are subjected to cyclical and temporary impacts, the origin of which is a consequence of multiple impacts of the aircraft on the pavement. These types of interactions include dynamic interactions. This publication considers the state of impact of aircraft on the pavement of planes standing on it. This type of vibration is complex and manifests itself in mechanical, acoustic, thermal, and other interactions, which are turbulent and of high intensity. The scale of the impact of aircraft on the pavement is a consequence of their design solutions, mainly the size of the engine thrust and the aircraft operating time in various power ranges and the method of transferring the load to the pavement, as well as solutions of the pavement structural system.

\section{The method of dynamic field tests}

The tests of the dynamic impact of aircraft on the pavement were performed on an experimental part of the engine test plane. The source of dynamic excitations were two types of aircraft, ie TS 11 Iskra, SU-7-BM and SU-22M4. The basic characteristics of these aircraft influencing the generated impact are as follows: for the TS 11 Iskra aircraft, the amount of thrust $795 \mathrm{dkN}$ and take-off weight of $3834 \mathrm{~kg}$, for the SU-7- BM aircraft, the amount of thrust of $6865 \mathrm{dkN}$ and the take-off weight of $13954 \mathrm{~kg}$. SU-22 M4 with a thrust of 7,500 dkN (with possible afterburner $11700 \mathrm{dkN}$ ) and a take-off weight of $19,500 \mathrm{~kg}$. The geometric shapes and their dimensions are shown in Figs. 1, 2, 3.

The research was carried out on the concrete, experimental pavement made of $14.0 \mathrm{~cm}$ thick prestressed slabs, which were placed on two types of substrate, i.e. 
- substructure made of C 8/10 concrete (formerly B 100),

- substructure with a leveling layer of compacted sand. The pressure in the tires was as follows: for wheels in the main landing gear, about 1.5 MPa, in the nose landing gear, about 1.1 MPa.

The main purpose of the work was to verify the correctness of the design of the pavement made of prestressed slabs and the response of such pavement to the dynamic effects of airplanes working on it. In order to obtain reliable, dynamic characteristics of the pavement, the seismic method was used, the essence of which is the possibility of determining the size of the propagation of elastic waves in a complex layered medium. The dynamic wave characteristics of the plane-surface system consisted of; determining the speed of wave propagation, vibration frequency, and the amount of damping. In order to assess the nature of the phenomenon, the following were determined: maximum amplitudes and the dominant frequency of vibrations. The measurements primarily took into account vertical load components. The vibration recorders were electrodynamic geophones with a natural frequency of $10 \mathrm{~Hz}$. The recording equipment is a set of ASI-415 devices. The characteristic size of the recording device is:

- band of recorded frequencies 2.5 to $1200 \mathrm{~Hz}$,

- dynamics of gain control $66 \mathrm{~dB}$. The geophones were inserted in the places marked in Fig. 1, 2, 3 and in the axis of the plane at a distance of about $3.0 \mathrm{~m}$ from each other in a straight line.

Measurements were carried out with increasing load dynamics according to the following principles:

- starting, engine thrust approx. 5\% of maximum thrust,

- low gas, engine thrust approx. $10 \%$ of maximum thrust.

- operational condition, the thrust was about $45-58 \%$ of the maximum thrust,

- the maximum state possible to be realized in the proving ground conditions, thrust force about $95 \%$ of the maximum thrust.

For each condition, the vibration characteristics of the aircraft assembly and the tested pavement were measured. The measurement results were recorded on a photographic film.
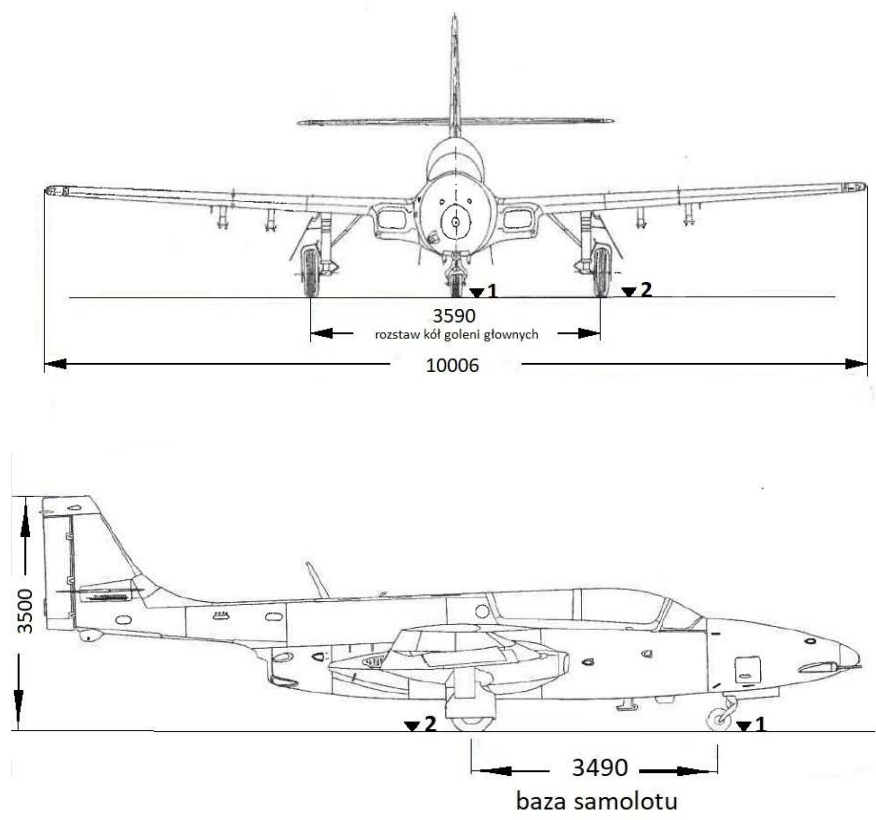

1. The TS-11 ISKRA airplane in the study of dynamic effects on the airport pavement 

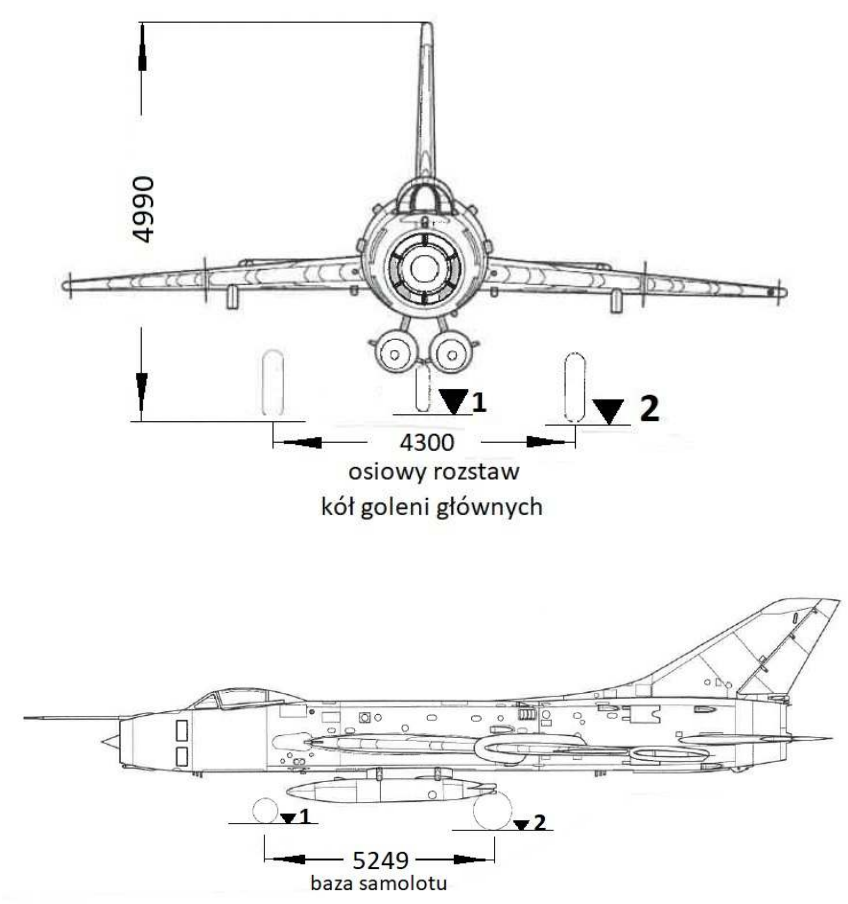

2. The SU-7-BM airplane in the study of dynamic effects on the airport pavement
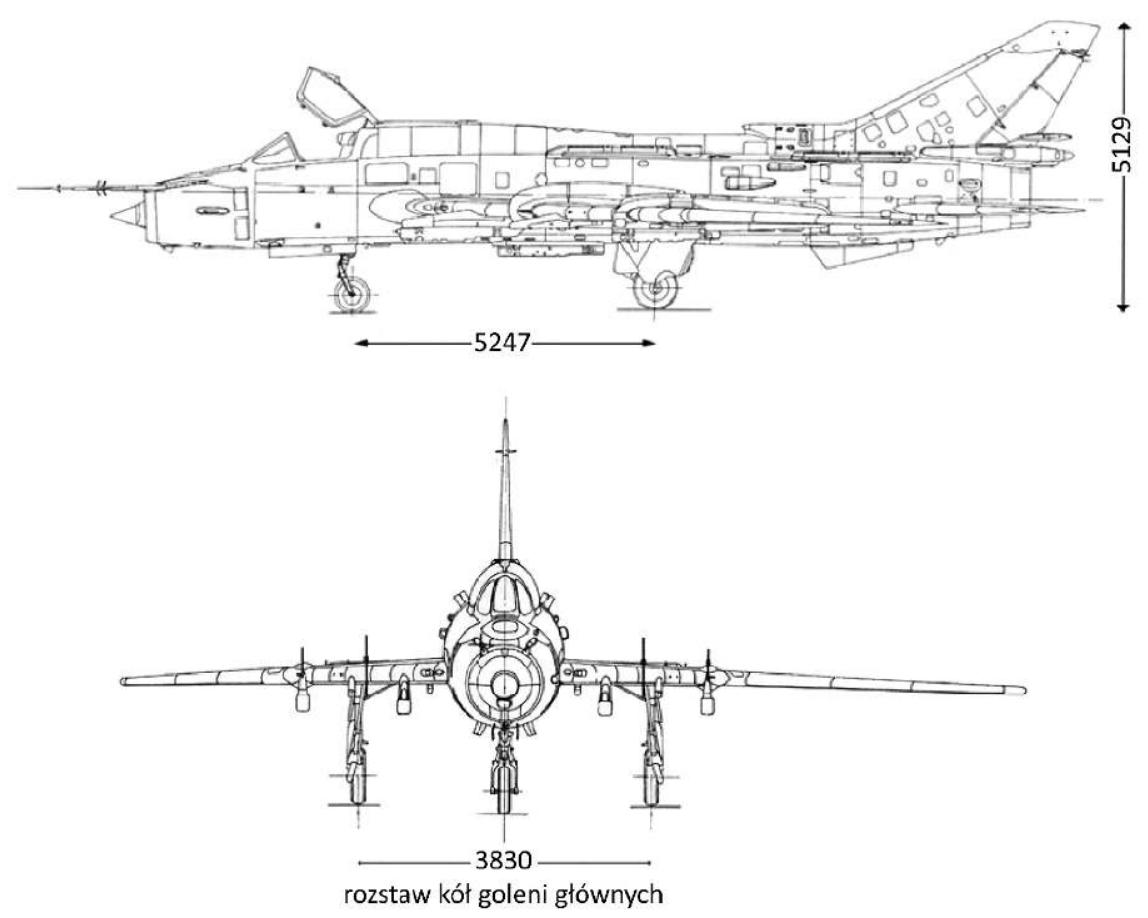

3. The SU-22 M4 aircraft in the study of dynamic effects on the airport pavement The markings 1, 2, 3 refer to the location of measurement geophones for all types of aircraft used in the research. Aircraft dimensions are given in $\mathrm{cm}$.

\section{Test results obtained in field measurements}

The conducted research allowed for the registration of the longitudinal wave propagating under the pavement in the base layer, which, as previously signaled, had different material characteristics. From the analysis of the longitudinal wave velocity in the substrate layer, 
regardless of the type of layers, no significant differences in their courses, i.e. their velocity, were observed. The velocity of the elastic longitudinal wave was from 1800 to $1900 \mathrm{~m} / \mathrm{s}$. It should be borne in mind that the measurements of the dynamic impact of aircraft on airport pavements were the first in the country. Until now, there are no rational criteria for assessing such impacts. National standardization documents apply to general construction buildings and structures and a standard was developed for this type of facility, which was updated in 2016 and is currently in use in the PN-B -02170: 2016-12 version. "Assessment of the harmfulness of vibrations transmitted through the ground onto buildings". It was this standard that constituted the reference level to the results obtained in the research. The measured vibration velocity amplitudes were converted into the displacement amplitudes according to the following dependence:

$$
\begin{aligned}
\mathrm{A}_{\mathrm{w}} & =\frac{A_{v}}{2 f} \\
\mathrm{Aa} & =2 \mathrm{Av} \mathrm{f}
\end{aligned}
$$

where : Aa - acceleration amplitude,

Av - velocity amplitude,

Aw - displacement amplitude,

f - frequency.

When analyzing the nature of the impact of aircraft on the airport pavement, we deal with paraseismic vibrations which are characterized by a non-stationary random process. When studying this class of impact, it means that in problems of this class, an individual approach and detailed analysis of phenomena are required, which will make the obtained result more reliable. Depending on the level of the engines' operation, the amplitudes of the vibration velocities changed. The highest amplitudes were recorded at the highest level of engine operation, close to the pre-launch regime. The amplitudes of the vibration velocities in the initial stage of the engine's operation are almost an order of magnitude lower than those obtained from the recordings when the aircraft engine showed the maximum thrust close to the pre-take-off regime. The recorded amplitudes of the vibration velocities A allow for the division according to the following groups :

- the greatest vibrations $A>0,200 \mathrm{~m} \mathrm{~m} / \mathrm{s}$,

- average vibrations $0,200>\mathrm{A}>0,100 \mathrm{~mm} / \mathrm{s}$,

- small vibrations $0,100>\mathrm{A}>0,060 \mathrm{~mm} / \mathrm{s}$,

- very small vibrations $0,060 \mathrm{~mm} / \mathrm{s}>\mathrm{A}$.

The obtained results of the field measurements are presented in Table $\mathbf{1}$. 
Tab. 1. Distribution of recorded vibrations of the pavement in particular groups depending on the pavement structure and the working airplane

\begin{tabular}{|c|c|c|c|c|c|}
\hline \multirow{2}{*}{$\begin{array}{l}\text { Type of } \\
\text { aircraft }\end{array}$} & \multirow{2}{*}{$\begin{array}{l}\text { Structural system of } \\
\text { the pavement on } \\
\text { which } \\
\text { measurements were } \\
\text { made }\end{array}$} & \multicolumn{4}{|c|}{ The size of the recorded amplitudes in $\mathrm{mm} / \mathrm{s}$} \\
\hline & & $\mathrm{A}>0,200$ & $\begin{array}{l}0,200>A> \\
0,100\end{array}$ & $\begin{array}{l}0,100>A> \\
0,060\end{array}$ & $\mathrm{~A}>0,060$ \\
\hline \multirow[t]{2}{*}{$\begin{array}{l}\text { TS-11- } \\
\text { ISKRA }\end{array}$} & $\begin{array}{l}\text { The compacted sandy } \\
\text { substrate, prestressed } \\
\text { plate, thickness } 14.0 \\
\text { cm }\end{array}$ & 0,24 & 0,41 & 0,32 & 0,03 \\
\hline & $\begin{array}{l}\text { Concrete substrate, } \\
\text { the surface made of } \\
\text { prestressed slabs }\end{array}$ & 0,25 & 0,51 & 0,13 & 0,11 \\
\hline \multirow[t]{2}{*}{$\begin{array}{l}\text { SU-7 - } \\
\text { BM }\end{array}$} & $\begin{array}{l}\text { The compacted sandy } \\
\text { substrate, prestressed } \\
\text { plate, thickness } 14.0 \\
\text { cm }\end{array}$ & 0,25 & 0,70 & 0,02 & 0,03 \\
\hline & $\begin{array}{l}\text { The concrete } \\
\text { substrate, pavement } \\
\text { made of prestressed } \\
\text { slabs }\end{array}$ & 0,37 & 0,22 & 0,37 & 0,04 \\
\hline $\begin{array}{l}\text { SU-22 } \\
\text { M4. }\end{array}$ & $\begin{array}{lr}\text { Compacted } & \text { sandy } \\
\text { substrate, } & \text { concrete } \\
\text { slab } & \end{array}$ & 0,41 & 0,68 & 0,48 & 0,07 \\
\hline
\end{tabular}

By analyzing and comparing the characteristics of the aircraft used in the experiments, it can be concluded that:

- The frequency of vibrations caused by aircraft on the pavement with this design characteristic does not differ much from each other. Slightly higher amplitudes occurred in the case of the heavier SU-7-BM and SU-22 M4 aircraft,

- no significant discrepancies depending on the type of foundation and substrate were distinguished in the research. The registered maximum amplitudes of vibration velocities are as follows for the aircraft used in the experiment:

○ for the TS - 11 - Iskra aircraft,

- working on the base of compacted sand Amax $=0,244 \mathrm{~mm} / \mathrm{s}$ and $\mathrm{f}=99$ $\mathrm{Hz}$,

- working on the substrate of concrete class C8 / 10 Amax $=0,24 \mathrm{~mm} / \mathrm{s}$ and $\mathrm{f}=126,2 \mathrm{~Hz}$,

$\circ$ for the plane SU-7-BM,

- working on the substrate of compacted sand Amax $=0,239 \mathrm{~mm} / \mathrm{s}$ and $\mathrm{f}$ $=189 \mathrm{~Hz}$,

- working on the substrate of concrete class C8 / 10 Amax $=0,826 \mathrm{~mm} / \mathrm{s}$ and $\mathrm{f}=79,2 \mathrm{~Hz}$.

o for the SU-22 M4 aircraft on the C 25/30 concrete substrate (formerly B 25).

The occurrence of low-frequency vibrations ranging from 60 to $400 \mathrm{~Hz}$ and vibrations of higher frequencies, i.e. 600 to $1200 \mathrm{~Hz}$, was found. In the group of low-frequency vibrations, there were vibrations: for the TS-11-Iskra aircraft - $\mathrm{f}=187 \mathrm{~Hz}$, for the SU-7-BM aircraft $-\mathrm{f}=79 \mathrm{~Hz}$, for the SU-22 M4 aircraft - Amax $=1.93 \mathrm{~mm} / \mathrm{s}$ and $\mathrm{f}=125 \mathrm{~Hz}$ 
In the group of high-frequency vibrations for both aircraft, the recorded frequencies were similar and amounted to approximately $1260 \mathrm{~Hz}$. The highest amplitudes of vibrations were recorded by geophones located in the immediate vicinity of the main landing gear of the aircraft. The smallest amplitudes were recorded in geophones located directly at the nose wheel of the aircraft. The tests did not show any dependence of the velocity amplitude distribution on the position of the aircraft wheels in relation to the symmetry axis of the element (plate).

\section{Interpretation of the results of field tests}

Interpreting the obtained results of field tests in terms of their harmful effect on the airport pavement, the national standard PN-85 / B-02170 Assessment of the harmfulness of vibrations transmitted by the substrates to buildings and its newer version PN-B - 02170: $2016-12$ (with further amendments) was used. Using this standard, the author was aware that the assessment of the airport pavement structure in accordance with the above-mentioned standard is only a certain analogy to vibration phenomena and their effects occurring in cubature objects. There are no relevant normative acts for communication construction facilities, although many detailed studies have been prepared, among others, for the metro under construction, bridge structures, and others. The following criteria were used to assess the harmfulness of the impact of vibrations on the airport pavement:

- vibration velocity amplitudes,

- acceleration amplitudes - SWDI scale,

- shock indicators - Zeller scale,

- shock power factors - the scale of vibrators. In practice, the most common scales are based on the vibration velocity criterion. According to many authors, the critical vibration velocities above which damage to structures occur are: for residential buildings according to the authors of Dworzak and Sadowski $100 \mathrm{~mm} / \mathrm{s}$, for industrial buildings according to Morris $40 \mathrm{~mm} / \mathrm{s}$, Kohler $5 \mathrm{~mm} / \mathrm{s}$. Some of those who study the issue of wave propagation in complex media, which can include the coupled system base and subsoil, define the vibration velocity at the level of $2 \mathrm{~mm} / \mathrm{s}$.

Own analysis of the problem according to which the maximum vibration velocity is $0.826 \mathrm{~mm} / \mathrm{s}$ and the comparison of its results with the proposals of the cited authors is definitely divergent and is lower than the above-mentioned proposals. In further analysis, in order to compare the obtained results with other criteria, velocity amplitudes were converted into accelerations according to the following scales: SWD-1 (Dynamic Shocks Scale), Zeller's scale - the scale of shock indicators and the shock power scale (vibrator scale). The calculated quantities are as follows:

1. SWD-1 scale. The range of calculated accelerations $b=(0.596-15,176 \mathrm{~cm} \mathrm{~s}-2)$ these vibrations are not dangerous for the building. For the maximum acceleration bmax $=$ $41.00 \mathrm{~cm} \mathrm{~s}-2$, the vibrations recorded for the building but not dangerous in terms of its durability. The amplitudes of vibration velocity and acceleration were determined from the dependence (2).

2. Zeller scale. For maximum values $\max =21.28 \mathrm{~cm} 2 \mathrm{~s}-3-$ weak vibrations. The remaining values are within the limits of imperceptible vibrations. The assessments were made using the dependence (3).

$$
\chi=\frac{A_{u}^{2}}{f}
$$

In which:

$\mathrm{Au}-$ amplitude of vibration acceleration in $\mathrm{mm} \mathrm{s}-2$,

$\chi$ - shock index in s mm2 s -3, 
$\mathrm{f}$ - oscillation frequency $\mathrm{Hz}$.

3. The scale of vibrators - the scale for assessing acceleration and vibration frequency is a compilation of these phenomena - it informs about the sensitivity of the structure to shocks. The maximum values of the shock power factor Smax $=23.22$ classifies the phenomenon as weak vibrations, without damage to the structure, however, after a longer period of time, the appearance of the first micro-cracks in the structure can be observed. The shock power factor was determined from the dependence (4).

$$
\mathrm{S}=10 \log \frac{\theta}{\theta_{0}}
$$

In which:

$\theta$ - is an indicator of the shock power in $\mathrm{cm}^{2} \mathrm{~s}^{-3}$,

$\theta_{0}$ - is a comparative shock index for the structure in question, its value can be taken as $0,1 \mathrm{~cm}^{2} \mathrm{~s}^{-3}$.

In order to determine the multiplication of displacements under the influence of the dynamic effects of aircraft, the multiplication factor was calculated. It was assumed that the slab, due to its high stiffness, is treated as a system with one degree of freedom, the substrate was modeled with a spring of a certain stiffness. The dynamic coefficient was determined from the dependence (5).

$$
\mathrm{K}_{\mathrm{d}}=\frac{1}{\sqrt{\left(1-\beta^{2}\right)}+4 b \beta^{2}}
$$

In which :

$\mathrm{kd}$ - dynamic factor,

$\beta=\frac{p}{\omega}-\mathrm{p}-$ the frequency of the driving force,

$\omega$ - natural frequency,

$\mathrm{b}$ - the magnitude of damping.

The natural frequency was determined from the dependence (6).

$$
\omega=4,98\left(\frac{K}{G}\right)^{1 / 2}
$$

In which:

$\mathrm{G}$ - the size of the load,

$\mathrm{K}$ - spring constant.

The determined frequencies of natural vibrations are respectively:

- for a slab on a concrete substrate $\omega=25,89 \mathrm{~Hz}$,

- for a slab on a substrate of compacted sand and soil $\omega=16,70 \mathrm{~Hz}$.

The frequency of natural ground vibrations was determined from the dependence (7).

$$
\mathrm{f}_{\mathrm{z}}=\frac{1}{2 \pi} \sqrt{\frac{C_{z} F}{m}}
$$

In which:

$\mathrm{f}_{\mathrm{z}}$ - frequency of natural ground vibrations,

$\mathrm{F}$ - plate area in $\mathrm{m}^{2}$,

$\mathrm{m}$ - vibrating mass,

$\mathrm{C}_{\mathrm{z}}$ - the factor depends on the dimensions of the slab, pressure on the ground and its characteristics.

The determined frequency of natural vibrations of the subsoil was $\mathrm{fz}=21.37 \mathrm{~Hz}$. When calculating the coefficient, the value of the frequency of vibrations of the exciting force closest to the value of the natural frequency was adopted, they are respectively: 
- for slabs on a concrete substrate $\beta=2,43$,

- for slabs on sandy and soil ground $\beta=3,77$. For the native soil, this coefficient is $\beta=$ 2,97 .

The impact of damping is very significant in the area close to the resonance when $\beta=$ 1,0 , therefore the calculated values of this coefficient for various pavement design systems are above the resonance of $\beta>1,0$, and consequently, the damping was omitted. Assuming $\mathrm{b}=$ 0 , the formula for the value of the dynamic coefficient will take the form (8).

$$
\mathrm{K}_{\mathrm{d}}=\frac{1}{\mathrm{I}\left(1-\beta^{2}\right) \mathrm{I}}
$$

The numerical value of the dynamic coefficient for the considered airport pavement structure is respectively:

- for slabs on a concrete substrate $K_{d}=0,204$,

- for slabs on sandy and soil ground $\mathrm{K}_{\mathrm{d}}=0,076$,

- for native soil, the coefficient is $\mathrm{K}_{\mathrm{d}}=0,130$.

Soil resonance frequencies may change with the depth and for subsoils under pavements, it should be determined at the load-bearing soil level where the pavement bed is located. Knowing the resonance frequencies allows you to avoid excessive vibrations or local settlement of the slab under dynamic loads.

In the analyzed problem, a significant impact of vibration damping on the pavement structure can be clearly observed. Along with the increasing distance from the vibration source, the vibration amplitudes decrease. One of the reasons for the amplitude decay along with the distance from the source of excitations is the geometric damping. The effect of this is the dissipation of wave energy in the elastic semi-space. The propagated waves in the medium along with their distance show an increase in the wave front and a decrease in energy density, and thus a decrease in vibration amplitudes.

\section{Conclusions}

The scope of the research carried out and their interpretation allow the following conclusions to be presented:

1. The most frequent amplitudes occur in the frequency range for the TS-11-Iskra from 95 to $315 \mathrm{~Hz}$, for the SU-7-BM from 85 to $270 \mathrm{~Hz}$, for the SU-22M4 from 62 to 125 $\mathrm{Hz}$.

2. The greatest amplitudes were registered by sensors located directly at the wheels of the main landing gear.

3. The frequencies of vibrations caused by the aircraft used in the tests do not show any significant differences. The occurring frequency differences are mainly caused by the physical and mechanical properties of the subsoil.

4. There were no significant differences in vibrations depending on the type of foundation. In the analysis of the phenomenon, various factors were noticed, which draw attention to the fact that the frequency corresponding to the maximum vibration amplitude of the ground base and the concrete base is not the only measure of the phenomenon. It also depends on the distribution of loads transferred from the aircraft to the pavement, the connection of the "coupling between working airplanes and the pavement" as well as the spatial stiffness of the ground and pavement.

5. The maximum magnitudes of the amplitudes were recorded during the aircraft engine press, similar to the pre-take-off work regime. Velocity amplitudes are greater for aircraft with higher take-off weight. The largest of the recorded amplitudes is $\mathrm{A}=193$ $\mathrm{mm} / \mathrm{s}$ and $\mathrm{f}=125 \mathrm{~Hz}$, and is a consequence of the aircraft's operation on the "thrust" that can be obtained in the proving ground test. 
6. The analysis of the phenomenon for aircraft allows distinguishing two ranges of vibrations: with low frequencies from 60 to $400 \mathrm{~Hz}$ and with high frequencies 600 to $1200 \mathrm{~Hz}$.

7. The calculated values of the dynamic coefficient were related to the type of the applied layered structure of the structure - mainly the subsoil and the foundation. The numerical values of the dynamic coefficient range from $\mathbf{k}_{\mathbf{d}}=0.076$ to 0.204 , they are relatively low. This proves that the multiplication of displacements is relatively small. The related frequency of the exciting force is above the resonance, i.e. when $\beta>1$.

The conducted field measurements are the only ones in the country, the analysis of the phenomenon responds to some phenomena related to the dynamic diagnostics of airport pavements. The field of the dynamic impact of vibrations on cubature structures is already well developed, in the field of transport and airport construction, there is very little work in this field and the issues presented in this publication are few. The analysis of the dynamic impacts on the airport pavement should take into account the impact of these phenomena, also on the surrounding technical infrastructure. The presented considerations justify the need to develop a new research direction related to the dynamic diagnostics of such structures.

\section{Source materials}

[1] Ciesielski R. Ujęcie obliczeniowe oraz ocena wpływu drgań i wstrząsów pochodzących ze źródeł zewnętrznych na niektóre typy budowli. Zeszyty Naukowe Politechniki Krakowskiej- Budownictwo Lądowe Z.1.

[2] Kawecki J., Stypuła K.: Zapewnienie komfortu wibracyjnego ludziom w budynkach narażonych na oddziaływania komunikacyjne. Wydawnictwo Politechniki Krakowskiej. Kraków 2013.

[3] Nita P.: Dynamiczne oddziaływanie pracującego statku powietrznego na betonowa nawierzchnię lotniskową . Acta Sci. Pol. Architektura 169302017 str. 119-127.

[4] PN-B- 02170:2016-12 Ocena szkodliwości drgań przekazywanych przez podłoże na budynki. 